\title{
प्रमुख सिरमौरी वादक कलाकारों का सांगीतिक योगदान
}

\section{डॉ० शिवराम'}

हिमाचल प्रदेश की जनपद् ईकाईयों में से एक सिरमौर जनपद् प्रदेश का ताज कहलाता है। बहुमूल्य वनों से सुशोभित, खनिज सम्पदा से समृद्ध तथा नैसर्गिक सौन्द्य से भरपूर सिरमौर रियासती काल से ही विश्टि स्थान रखता है। शाब्दिक अर्थ में सिरमौर दो शब्दों के मेल से बना है - 'सिर' तथा 'मौड़'। मौड़ सिरमौरी लोक-भाषा में सिर पर लगाए जाने वाले मुकुट को कहते हैं। यही सिरमौड़ कालान्तर में बिगड़कर 'सरमोर' अथवा 'सिरमौर' बन गया। सम्प्रति 'सिरमौर' नाम से कोई स्थान विशेष नहीं मिलता। भौगोलिक रूप से सिरमौर जनपद् हिमाचल प्रदेश के दक्षिणी भाग में अवस्थित है। इस जनपद् की सीमाएँ उत्तर दिशा में प्रदेश के जिला शिमला तथा पश्चिम में जिला सोलन से लगती हैं जब कि इस के पूर्वी भाग में उत्तराखण्ड तथा दक्षिण में हरियाणा राज्य की सीमाएँ छूती हैं।

यहां के लोग धर्म-परायण, भोले-भाले तथा चरित्रशील हैं। इस जनपद् की लोक-संस्कृति पूरे प्रदेश में विशेष महत्व रखती है। विभिन्न धार्मिक एवं लौकिक आयोजनों पर गायन एवं नृत्य कला प्रेमी अपनी गायन एवं नृत्य कला की छटा बिखेरते हैं। सिरमौर जनपद् के विशिष्ट वाद्य यन्त्रों के संगीत के बिना, गायन एवं नृत्य न केवल अधूरा लगता है बल्कि असम्भव बन जाता है।

त्यौहार तथा मेले यहां की लोक संस्कृति के अभिन्न अंग हैं। सिरमौर जनपद् में वर्ष के बारह मासों में से हर मास कोई न कोई त्योहार अवश्य मनाया जाता है। इन त्योहारों की विशेषता यह है कि इनमें प्रत्येक त्योहार से लोक प्रचलित कोई न कोई पौराणिक घटनाएं जुड़ी हैं ऐसा लोगों का विश्वास है। इन त्योहारों में क्रमशः - चैत्रमास का त्योहार, बिशु-त्योहार, जेठोरा मोऊल, हरियाली, शोणयाली, कृष्ण जन्माष्टमी, पा०चोई, ओशाउजोरी आठोई, विजय दशमी, गरबड़े, नई-दीवाली तथा बूढ़ी दीवाली, माघी त्योहार, खोड़ा त्योहार, शिवरात्री तथा होली का त्योहार धूम-धाम से मनाए जाते हैं।

\section{सिरमौर जनपद का लोक-संगीत}

सिरमौर जनपद् में लोक संगीत का अपार भण्डार है। सिरमौरी लोक संगीत भूतकाल से लेकर वर्तमान काल तक समृद्ध शील है। यहां के जनमानस ने आज के बदलते हुए वैज्ञानिक परिवेश में अपनी लोक संगीत रूपी धरोहर को जीवित रखा हुआ है। इसने अपने परम्परागत लोक संगीत की रक्षा ही नहीं की है बल्कि इसे और परिष्कृत करने का भी प्रयत्न किया है। यहां के लोक संगीतज्ञों ने अपने प्रदेश ही नहीं बल्कि देश-विदेश के विभिन्न भागों में अपनी लोक-संस्कृति का उत्कृष्ट प्रदर्शन कर अपनी अमूल्य संस्कृति को चार चान्द लगाए हैं। रेणुका जी, शिलाई तथा राजगढ़ (पच्छाद) जैसे पिछड़े क्षेत्र के लोगों ने अपने परम्परागत गीतों एवं लोक-नृत्यों, नाटी, झूरी, रासा, हारूल और बूढ़ा इत्यादि लोक सांगीतिक परम्पराओं को सुरक्षित किया है।

यहां की स्त्रियां पुरुषों के साथ मनोरंजन तथा समारोहों में भी सम्मिलित होती रहती हैं। यहां विवाह तथा जन्मोत्सव आदि के गीत केवल स्त्रियों द्वारा गाए जाने वाले गीत होते हैं। इसी प्रकार कुछ विशेष प्रकार के लोक-गीत जैसे लोक-गाथाएं, हारें, देवी-देवताओं से सम्बन्धित गीत केवल पुरुषों द्वारा ही गाए जाते हैं। शेष लगभग सभी प्रकार के गीत, कथाएं तथा अन्य लोक सुभाषित स्त्रियों तथा पुरुषों द्वारा व्यक्तिगत अथवा सम्मिलित रूप से गाए एवं वर्णित किए जाते हैं।

सिरमौर जनपद् के लोक-नृत्यों तथा लोक गीतों में मुख्यतः अलग-अलग प्रकार के सिरमौरी वाद्य प्रयुक्त किए जाते हैं। इन नृत्यों में क्रमशः; नगाडा, दुमैनू (दमामा) छड़ी की ढोल, ढोलक, खंजरी, हुलकी, मंजीरा, छणका, रणसिंगा, करनाला तथा स्वर वाद्य के रूप में शहनाई तथा बांसुरी का प्रयोग भी देखने को मिलता है। प्रकृति के उन्मुक्त वातावरण में आज भी लोकसंगीत पुष्पित तथा पल्वित हो रहा है, आज भी लोक संगीत कृत्रिमता से दूर है। इसमें ताल यन्त्रों का प्रभुभ्व विद्यमान है। लोक-नृत्यों में लोकवाद्यों की संगत के बिना नृत्य एवं गीत दोनों ही पंगु है। लोकगीत एवं लोक नृत्य दोनों में ही वाद्यों की आवश्यकता समान रूप से होती है। इन दोनों विधाओं में प्राण डालने की भूमिका वाद्य यन्त्र ही निभाते हैं। 


\section{सिरमौर के लोक वाद्य}

सिरमौरी जन समुदाय जीवन संगीत के बहुमान्य आदि-प्रवर्तक भगवान शिव की सांगीतिक धरोहर को सुरक्षित रखे हुए हैं। इसका स्पष्ट प्रमाण यहाँ का सरल लोक जीवन, मधुर कंठसंगीत, पारम्परिक लोक वाद्य व वाद्य संगीत तथा आकर्षक लास्य पूर्ण नृत्य। संगीत के ये तीनों पक्ष सिरमौरी लोक संगीत में उजागर हैं, और इनका मधुर आकर्षक, लालित्यपूर्ण तथा स्वाभाविक रूप यहां दृष्टिगोचर होता है। गीत एवं नृत्य की भांति ही सिरमौर का पारम्परिक वाद्य-संगीत भी सुप्रसिद्ध है। जन्म से मृत्युपर्यंत, जीवन के विभिन्न चरणों में हर्ष-विषाद के अवसरों तथा विभिन्न मान्यताओं व चुनौतियों के अनुरूप वाद्य वादन की परम्परा सिरमौरी वाद्य संगीत की व्यापकता व विविधता का परिचायक है।

सिरमौरी लोक-वाद्यों में सुषिर, अवनद्ध तथा घन, तीन प्रकार के पारम्परिक लोक वाद्य विद्यमान हैं। यहां ढोल, नगाड़ा दुमैनू, मंजीरा छैणा, रणसिंगा, करनाल, खंजरी, हुलकी, ढाकुली, कांस्य थाली, घड़ा, डमरू, छड़ियाल, भायण, शहनाई तथा बांसुरी आदि। इन लोक वाद्यों में बांसुरी, ढोलक और खंजरी वाद्यों को छोड़कर शेष वाद्य विवाह, पुत्र-जन्म, मेलों व जात्तरा जैसे विशेष अवसरों पर तथा देव स्थानों पर बजाए जाते हैं। इन विशेष अवसरों पर श्रृंगारिक लोक-संगीत में प्रयुक्त होने वाले ढोल, शहनाई व नगाड़ा आदि वाद्य भी सम्मिलित होते हैं। बांसुरी, खंजरी और ढोलक आदि वाद्य प्रायः श्रृंगारिक लोक-संगीत के वाद्य है।

\section{वादक कलाकार}

सिरमौर जनपद् में लोक संगीत के वाद्यों के वादन का बहुत महत्व है। इन वाद्यों के वादन का सम्बन्ध विशेषतयः समाज के निम्न वर्ग के लोगों से जुड़ा हुआ है। ये लोग वाद्यों के वादन को व्यवसाय के रूप में करते हैं। मांगलिक कार्यों के अवसर पर तथा देवालय (मन्दिर) में मात्र तूरी, ढाकी, लुहार आदि जाति के लोग ही वाद्यों का वादन करते हैं। इनके अलावा, कोली, डूम, चमार तथा चनाल और तेली आदि जाति के लोगों को देवता के समीप और उच्च वर्ग के लोगों के घर व आंगन में आगे बैठने की सिरमौरी समाज में इज़ाजत नहीं है। कोली, डूम तथा चमार आदि जाति के लोग केवल मात्र धौंकनी वीणा और ढोल आदि वाद्यों का वादन बैण्ड बाजे के रूप में विवाह शादियों तथा किसी राजनीतिक मेहमान के स्वागत में ही करते हैं। उपरोक्त वर्ग वाद्य वादन के व्यवसाय से अपनी आजीविका कमाते हैं तथा अपने परिवार का पालन पोषण करते हैं। जो वादक कलाकार विशेष देवधरा से जुड़े हैं उन्हें गाँव की ओर से देवालय में सुबह-शाम, वाद्य-वादन करने के लिए हर माह मेहनताना के रूप में आटा, चावल एवं दालें ग्रामीणों द्वारा दी जाती हैं। ये लोग जन्म संस्कार से लेकर अन्त्येष्टि तक का वाद्य वादन करते हैं।

\section{अवनद्ध वाद्य वादक}

इस श्रेणी में सिरमौर जनपद् में ढोल, नगाड़ा, दमामा, दुमैनू, ढाकुली, डमरू तथा हुलकी आदि वाद्यों को बजाने वाले वादक कलाकार आते हैं। वाद्य वादकों की इस श्रेणी में ज्यादा संख्या में कलाकार पाए जाते हैं। इस श्रेणी के वाद्य वादकों में मात्र ढोलक ही ऐसा वाद्य है जिसे उच्च वर्ग के लोग भी बजाते हैं तथा ढोलक वाद्य सिरमौर में लगभग हर घर तथा प्रत्येक गाँव में देखने को मिलता है।

\section{नरेश कुमार}

नरेश कुमार मृदुभाषी एवं शान्त स्वभाव के व्यक्ति हैं। आपके पिता स्वर्गीय श्री शिगड़ाराम जी न केवल ढोल नगाड़ा ही बजाते थे अपितु सिरमौरी लोक संगीत की विभिन्न विधाओं एवं विभिन्न प्रकार के वाद्यों के वादन एवं नृत्य का भी उन्हें भरूपर ज्ञान था। इसी सांगीतिक माहौल में 14 अप्रैल सन् 1959 को रेणुका जी विधान सभा क्षेत्र के रावलागढ़ नामक स्थान पर नरेश कुमार का जन्म हुआ। पिता तथा दादा जी द्वारा बाल्यकाल में ही आपकी संगीत शिक्षा प्रारम्भ हो गई। 10-11 वर्ष की आयु में

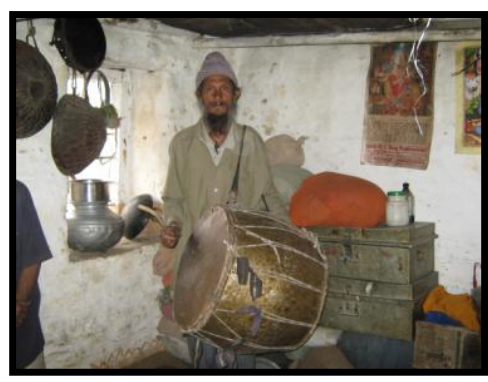
ही नरेश कुमार अच्छा ढोल एवं नगार-जोड़ी बजाने लग गए। धीरे-धीरे आपने वाद्य-वादन में अच्छी महारत हासिल कर ली। 
नरेश कुमार के वाद्य वादन में चैन दारी, मधुरता और सफाई विशेष रूप से विद्यमान रहती है। घर में गरीबी का साम्राज्य होने के कारण पांचवीं कक्षा तक ही पढ़ाई करने के पश्चात देवता बिजट महाराज, रावलागढ़ के मन्दिर में पूजा पाठ के समय सुबह-शाम नगाड़ा वादन करते हुए आपने जीवन निर्वाह करना शुरू किया तथा यहीं से ही परिवार का पालन पोषण करते हैं। इसके अलावा विवाह शादियों तथा सामूहिक आयोजनों एवं स्थानीय मेलों में भी वाद्य वादन करने का शौक रखते हैं नरेश कुमार व्यवसायी नगाड़ा वादक हैं तथा कई पीढ़ियों से संगीत का इनके परिवार में अच्छा खासा माहौल है। नरेश कुमार अपने पुत्रों सुरेन्द्र कुमार और जगत सिंह के अलावा और भी संगीत का शौक रखने वाले गांव के बच्चों को निशुल्क ढोलक एवं गाना सिखाते हैं।

\section{दीपराम धीमान}

नगार जोड़ी के धुरन्धर वादक, श्री दीपराम धीमान, सपुत्र स्व० नन्दू राम को नगार जोड़ी वादन की तालीम अपने स्व0 दादा श्री गोसाई राम तथा स्व० पिता श्री नन्दू राम से प्राप्त हुई। सिरमौर जनपद् के उत्कृष्ट नगाड़ा वादकों में आपका नाम लिया जाता है। व्यवसायिक नगाड़ा वादक के साथ-साथ लोहे का कारोबार भी आप करते हैं। आपके वादन में बोलों की स्पष्टता तथा दमदार निकासी एक विशेषता है। आपका जन्म रेणुका जी विधान सभा क्षेत्र की संगड़ाह तहसील के बाऊनल गाँव में 1 मई 1945 को हुआ। बचपन से ही आपको वाद्यों के वादन का शौक था अतः आपने अपने पूर्वजों से ही इसके समबन्ध में ज्ञान अर्जित किया तथा खूब नाम कमाया आप देवता के साथ नगार जोड़ी बजाते हैं तथा सिरमौरी लोक तालों का अच्छा ज्ञान रखते हैं। नगार जोड़ी के अलावा ढोलक भी आप अच्छी बजाते हैं। आपके शिष्यों में श्री तुलसी राम रजाना तथा नीका राम बाऊनल और राजू

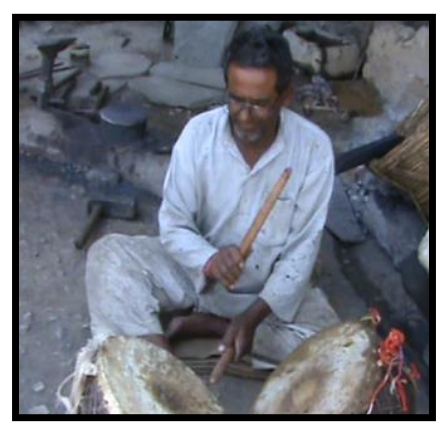
अन्धेरी उल्लेखनीय हैं। आपके ज्येष्ठ पुत्र हेतराम भी एक कुशल नगाड़ा वादक हैं। फुलणिया ताल तथा सुबह-शाम की नबद बजाने में आपकी विशेष महारत है।

\section{जसवन्त}

सिरमौर जनपद् के वर्तमान नगारचीयों (नगार जोड़ी वादकों) में जसवन्त का अपना अलग स्थान है। आप अपने स्वर्गीय पिता श्री सालीगराम के ही शिष्य हैं तथा कुछ समय अपने मामा से भी सीखने का अवसर प्राप्त हुआ। आपका जन्म 9 मई, 1967 को रेणुका जी विधान सभा क्षेत्र की संगड़ाह तहसील के लगनू गाँव में हुआ। आपके पिता जी की वृद्धावस्था होने के कारण आपकी मां शान्ति देवी आपको बाल्यवस्था में अकेला छोड़कर चली गई। माँ का अभाव और पिता की वृद्धावस्था उपर से आंखों का अन्धा होना

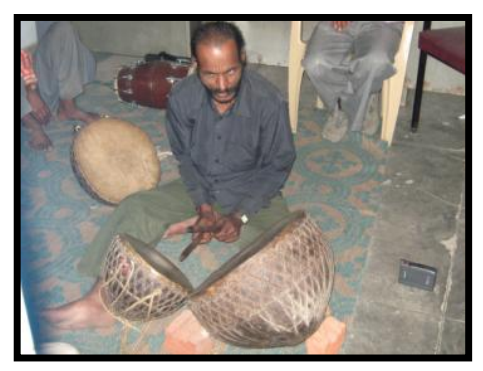
जसवन्त के लिए एक चुनौती पूर्ण जीवन की शुरूआत थी। वृद्ध पिता ने जैसे-तैसे आपका पालन पोषण किया और नगार जोड़ी बजाने तथा ढोलक बज़ाने का प्रशिक्षण स्वयं ही दिया। आपको जो कुछ भी सिखाया वह आपने यथावत कण्ठस्थ कर लिया। लोक तालों के बारे में जो चीजें आपको सिखाई गई वह सभी आपको कण्ठस्थ हैं। आप एक अच्छे नगारची हैं तथा ढोलक भी अच्छी बजाते हैं। आप जो बोल व ताल बजाते हैं उसकी पढ़ंत भी भली-भान्ती बोलते हैं।

आप बिल्कुल अनपढ़ हैं पाठशाला कभी नहीं गए। आपकी आजीविका का साधन वाद्यों का वादन है। आप आजीवन ब्रह्मचारी हैं तथा अपने कुल के अन्तिम चिराग हैं। आपके स्व० पिता श्री सालिग राम एक उच्च कोटी के गवैये तथा वाद्य वाद्य वादक थे। आप एक सरल स्वभाव के इन्सान हैं। हर छोटे बड़े से नम्रता पूर्वक वार्तालाप करते हैं तथा सीखने वालों को अच्छे ढंग से सिखाते हैं। विवाह शादियों जन्मोत्सवों तथा मेलों आदि में आप अपने वाद्य दल के साथ वादन करने के लिए जाते हैं तथा लोगों का भरपूर मनोरंजन करते हैं। आपको सिरमौर जनपद् में बजाए जाने वाले लोक वाद्यों का अच्छा ज्ञान है। 


\section{रमेश चन्द}

रमेश चन्द नगाड़ा वादक का जन्म सन् 1974 में रेणुका जी विधान सभा क्षेत्र के संगड़ाह तहसील के कड़ोली गांव में कुन्दन सिंह के घर में हुआ। व्यावसायिक कृषक परिवार में जन्म होने के कारण आप पाठाशाला तो नहीं जा सके लेकिन खेती-बाड़ी के साथ-साथ आपने अपने पुर्वजों से लोक वाद्यों (नगाड़ा, दुमैनू तथा हुलकी) को बजाने का ज्ञान अर्जित किया। आप लोक गाथाओं, जिन्हें हारूल कहते हैं, और बुढु

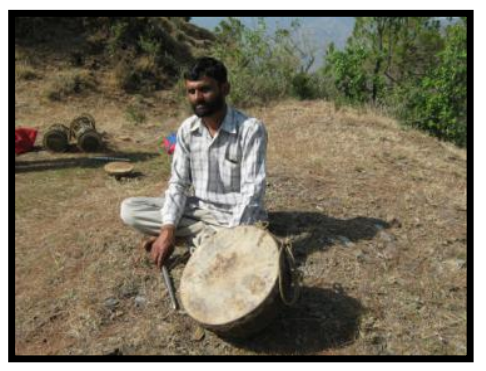
गायन अथवा बूढ़ा गायन के साथ नगाड़े की अच्छी संगत करते हैं। आपके वादन एवं गायन में स्वर माधुर्य की प्रधानता रहती है। आप लगभग प्रच्चीस वर्षों से लोक वाद्यों के बजाने का कार्य कर रहे हैं। बुढू के अलावा आप करियाला तथा रासा आदि में भी वादक की भूमिका निभाते हैं। आपके अलावा आपके परिवार में पांच बच्चे हैं, जिनमें दो बेटे व तीन बेटियां हैं आप अपने बच्चों का अच्छा पालन पोषण कर उन्हें पाठशाला की पढ़ाई भी करवा रहे हैं। कृषि कार्य के साथ-साथ आप वाद्य वादन से भी दूर नहीं रहते संगीत की सेवा का कार्य भी अच्छे ढ़ंग से कर रहे हैं।

\section{सूरत राम}

सन् 1954 के लगभग आपका जन्म सिरमौर जिला की संगड़ाह तहसील के कज़वा गाँव में हुआ। आपके पिता स्व० सालकु राम जी एक छोटे से किसान थे कृषि कार्य के साथ लोहार का काम तथा ढोल नगाड़ा बजाने का भी काम करते थे आपको 'नगार जोड़ी' बजाने की शिक्षा अपने स्व० पिता जी से ही मिली। आप विवाह शादियों तथा गाँव कज़वा के बिजट महाराज मन्दिर में लोक वाद्य बजाने का कार्य करते हैं

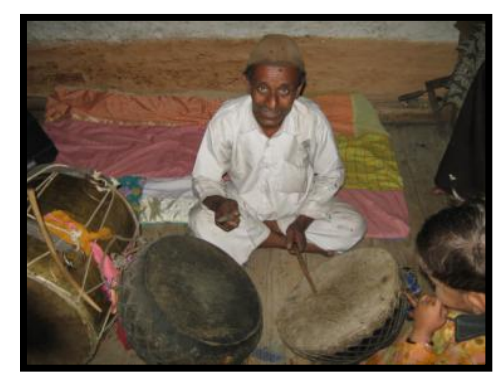
आप नगार जोड़ी के साथ-साथ ढोलक, ढोल एवं करनाल तथा रणसिंगा बजाने में भी निपुण हैं। आपके अलावा आपके घर में आपका बेटा हीरा सिंह भी ढोल, दुमैनू तथा रणसिंगा बजाने का शौक रखता है। आप सिरमौर जनपद् में बजाए जाने वाले सभी लोक वाद्यों का ज्ञान रखते हैं, तथा समयानुसार बजाने वाले लोक तालों जैसे वधावा, फुलणिया तथा देव भण्डारना बड़ी खूब-सूरती से बजाते हैं। आप लगभग चालीस वर्षों से सिरमौरी लोक संगीत की सेवा कर रहे हैं।

\section{सुन्दर सिंह}

सुन्दर सिंह का जन्म सन् 1975 के लगभग स्व० मोही राम के घर गाँव दिगुवा डाकघर मिला, तहसील शिलाई जिला सिरमौर में हुआ। आपके पिता स्व० मोही राम जी लोक-संगीत का अच्छा ज्ञान रखते थे अतः आप में यह गुण स्वभाविक है। आपने ढोल बजाना अपने पिता जी से ही सीखा। आप दिगुवा गाँव के परशु राम देवता के मन्दिर में ढोल, करनाल, रणसिंगा तथा ढोलक भी बजाते हैं। लोक वाद्य बजाना भी आपकी आजीविका का एक अहम पहलू है। आप विवाह शादियों एवं दूसरे सामाजिक उत्सवों में भी वाद्य बजाने का कार्य करते हैं।

\section{बस्ती राम}

सिरमौर यथा नाम तथा काम सिरमौर जनपद् हिमाचल के लोक संगीत में भी सिरमौर है। सिरमौर जनपद् के लोक वाद्यों की एक पृथक पहचान है। ढोल, दुमैनू वादक बस्ती राम का जन्म शिलाई तहसील के जरवा गाँव में स्वर्गीय सोभा राम के घर सन् 1949 में हुआ। आपको लोक वाद्य बजाने का प्रशिक्षण अपने परिवारिक महौल में ही प्राप्त हुआ। आपके पिता स्व० सोभा राम और दादा जी स्व० दांगी एक अच्छे
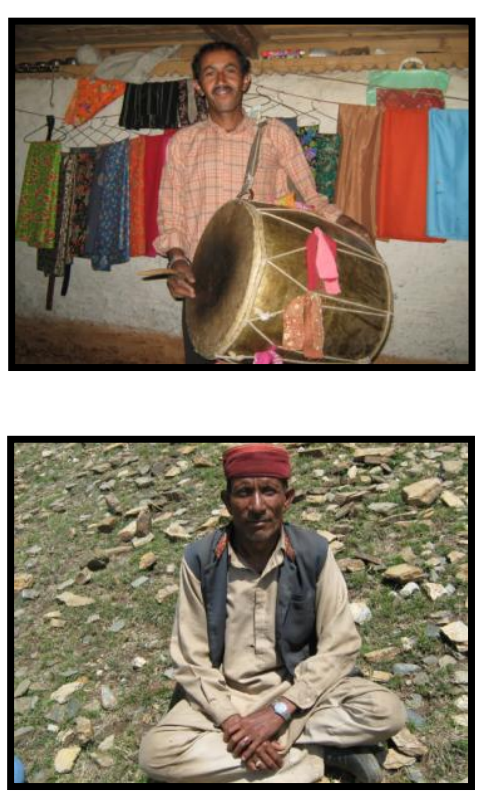
वादक कलाकार थे आप पारम्परिक लोक वाद्यदल जरवा के सदस्य वादक हैं। आप सिरमौर के अलावा हिमाचल के कई भागों में 
राष्ट्रीय एवं राज्य स्तरीय मेलों में अपने वाद्य वादन के कार्यक्रम प्रस्तुत कर चुके हैं। वाद्यों के वादन की परम्परा आपके परिवार में कई पिढ़ियों से चली आ रही है। आप बिजट महाराज के देवालय में भी वाद्य वादन करते हैं आप अपने क्षेत्र में बजने वाले लोक तालों का अच्छा ज्ञान रखते हैं आपके अलावा आपके परिवार में आपके ज्येष्ठ भ्राता श्री सालीग राम तथा आपके बेटे तोता राम, विक्रम तथा मुकेश लोक वाद्य बजाने का कार्य करते हैं। आपका परिवार एक व्यावसायिक संगीतज्ञ परिवार है।

\section{रमेश धीमान}

प्रतिभाशाली वादक कलाकार रमेश धीमान का जन्म श्री पलक राम धीमान गांव धरोटी तहसील राजगढ़ में 10 फरवरी सन् 1962 को हुआ। ज्येष्ठ एवं घर में प्रथम पुत्र होने के नाते आपका पालन पोषण बहुत ही लाड़ प्यार से हुआ। आपने वाल्यवस्था से ही लोक संगीत का ज्ञान अपने पूर्वजों से प्राप्त किया तत्पश्चात आठवीं कक्षा तक पढ़ाई पूरी करके आपने शास्त्रीय संगीत सम्बन्धी ज्ञान सेवानिवृत संगीत प्राध्यापक डॉ० कृष्ण लाल सहगल से प्राप्त किया तथा उन्हीं के सनिध्य में रहकर

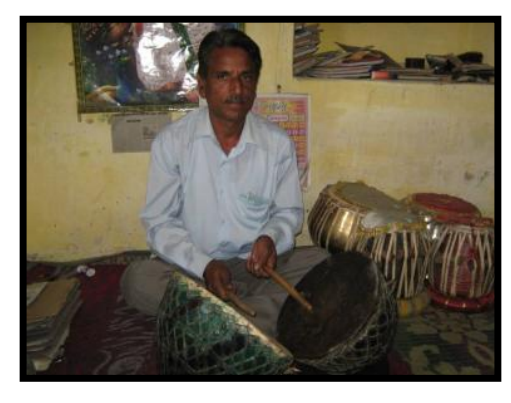
आपने तबला वादन में प्रभाकर की परीक्षा सन् 1998 में पास की। अभी भी आप डॉ० सहगल जी के सानिध्य में निरन्त संगीत का प्रशिक्षण ले रहे हैं तथा उन्हीं द्वारा संचालित 'स्वर साधना' संगीत कला केन्द्र में संगीत अध्यापन का कार्य भी करते हैं। आप संगीत सिखाने के साथ-साथ कैसेट रिकार्डिंग का कार्य करते हैं। नगार-जोड़ी वाद्य के वादन के साथ-साथ छटी की ढोल बजाने में भी सुप्रसिद्ध हैं। आपने क्षेत्र में बजने वाले लोक तालों का आपको अच्छा ज्ञान है।

आप संगीत के क्षेत्र में "साधना संगीत कला केन्द्र राजगढ़" में संगीत की सेवाएं दे रहे है। वर्ष 1995 में आकशवाणी शिमला से लोक वाद्य वादक की परीक्षा पास की तथा आजकल आप आकाशवाणी शिमला के नैमितिक बी-हाई ग्रेड कलाकार हैं। नार्थजोन कल्चर सेंटर के सौजन्य से आप देश के विभिन्न भागों कर्नाटक, हुगली, महाराष्ट्र, छतीसगढ़, रायपुर, दिल्ली एवं चण्डीगढ़ में कार्यक्रम प्रस्तुत कर चुके हैं।

\section{रणधीर कुमार}

रणधीर कुमार का जन्म 5 मई सन् 1966 को राजगढ़ तहसील के धरोटी गांव में हुआ। आपके पिता श्री पलक राम जी एक अच्छे ढोल वादक हैं। आपने छड़ी की ढोल बजाना अपने पिता एवं ज्येष्ठ भ्राता रमेश धीमान से सीखा। आप चुड़ेश्वर कला मंच के स्थाई वाद्य-वादक कलाकार हैं। हिमाचल प्रदेश तथा दूसरे राज्यों में कई कार्यक्रम पेश कर चुके हैं। आप नार्थजोन कल्चर सेन्टर की ओर से कर्नाटक, हुगली, महाराष्ट्र,

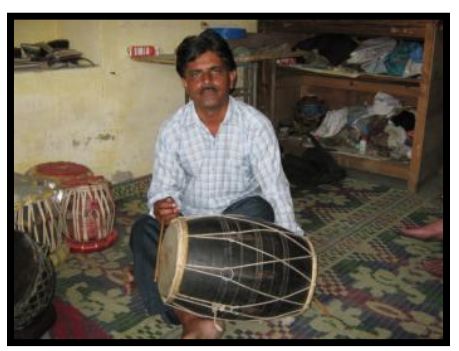
छत्तीसगढ़ तथा दिल्ली में कार्यक्रम दे चुके हैं। आपके परिवार में आपकी दो बेटियां कल्पना और करूणा हैं जो दोनों ही शास्त्रीय गायन सीख रही हैं।

\section{तुलसी राम}

नगार जोड़ी वादक तुलसी राम का जन्म गाँव रजाना, रेणुकाजी जिला सिरमौर में सन् 1959 ईं में हुआ। आपको नगार जोड़ी बजाने का प्रशिक्षण अपने स्व० पिता श्री साध राम से प्राप्त हुआ। आप अपने वाद्य वादन में एक कुशल वादक हैं। नगार जोड़ी के साथ-साथ आप ढोलक बजाने में भी सिद्धस्त हैं। बाऊनल लोक वाद्य दल के साथ आप कार्यक्रम प्रस्तुत करने जाते हैं। आप विवाह शादियों तथा अन्य सामाजिक उत्सवों मेलों

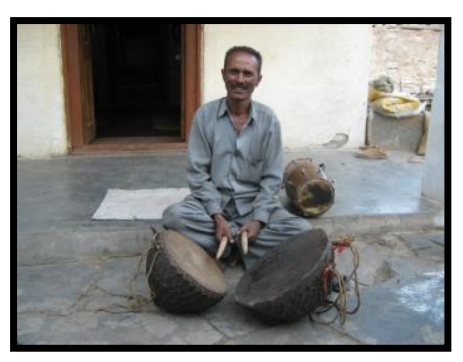
तथा देवपूजा आदि में भी नगार जोड़ी बजाने का कार्य करते हैं। अपने पिता जी के अलावा अपने बाऊनल के श्री दीपराम धीमान जी से भी नगाड़ा एवं ढोल बजाने की शिक्षा प्राप्त की आप अपने परिवार में एक मात्र सदस्य हैं। आपके परिवार में आगे कोई भी 
सन्तान लड़का अथवा लड़की कुछ भी पैदा नहीं हुए। आप नगाड़ा एवं ढोलक बजाकर तथा लोहार का व्यवसाय करके जीवनयापन कर रहे हैं।

\section{धर्म सिंह}

धर्म सिंह एक प्रतिभावान और कर्मठ पुरुष हैं। आप एक बहुमुखी प्रतिभा हैं। लोक वाद्यों का वादन, लोक गीतों का गायन, घुड़सवारी तथा शिकार खेलने में निपुण और अपने क्षेत्र में सुप्रसिद्ध व्यक्ति हैं। आपने लोक वाद्यों के वादन का ज्ञान अपने पुर्वजों तथा अपने बहनोई स्व० श्री शोभा राम जी (अन्धेरी वाले) से प्राप्त किया। आपका जन्म सन् 1949 में गाँव नया पंजोड़ त0 शिलाई जिला सिरमौर में हुआ। आपके पिता स्वर्गीय कलीराम धीमान

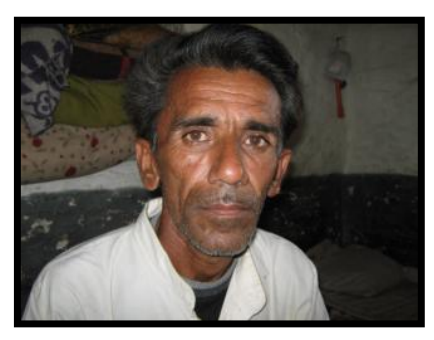
एक अच्छे कारीगर तथा अच्छे लोक गायक एवं वाद्य-वादक थे। उन्हें सिरमौरी लोक वाद्यों के साथ-साथ हारमोनियम और ढोलक बजाने का अच्छा ज्ञान था जो आपको विरासत में मिला। आप ठारी देवी और बिजट महाराज देवता के मन्दिर के वाद्य-वादक हैं। आपके परिवार में आपके दो बेटे संजय कुमार तथा मनोज कुमार वाद्य वादन का व्यवसाय करते हैं। आपका स्वास्थ्य लम्बे समय से खराब होने के कारण आप घर से बाहर इधर-उधर कहीं भी वाद्य वादन करने नहीं जाते।

\section{सुरेश कुमार}

रेणुका जी विधान सभा क्षेत्र की तहसील संगड़ाह के गाँव चाढ़ना में सन् 1978 में सुरेश कुमार का जन्म श्री देवी राम जी के घर एक लुहार परिवार में हुआ। आपको ढोल तथा नगाड़ा वाद्यों को बजाने का प्रशिक्षण अपने पूर्वजों से ही प्राप्त हुआ आप नृत्य गीत तथा वाद्यों के वादन में अत्यधिक रूची रखते हैं। भाटगढ़ के देवता परशु राम जी के मन्दिर में आप का परिवार कई पीढ़ियों से ढोल नगाड़ा आदि लोक वाद्यों को बजाने का कार्य कर रहा है। आप

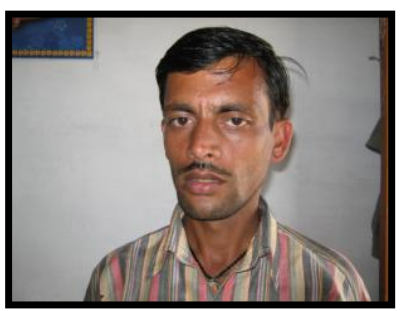
मन्दिर में बजाने के साथ-साथ विवाह शादियों में भी वाद्य वादन का व्यवसाय करते हैं। आप वाल्य वस्था से ही ढोल नगाड़ा बजा रहे हैं। आप वाद्य वादन के साथ लोक-गीत एवं नृत्य का भी अच्छा ज्ञान रखते हैं, तथा पारम्परिक लोक विधाओं के अनुभवी लोक संगीतज्ञ हैं। आपके परिवार में आपकी पत्नी तथा एक छोटी सी बेटी है।

\section{अमर सिंह}

नगाड़ा वादक अमर सिंह का जन्म 26 अक्तूबर सन् 1970 को रेणुका तहसील के रेडली गाँव में एक लोहार परिवार में हुआ। लोक-गीत गाने व लोक वाद्य बजाने की कला से आप अपने परिवार में ही परिचित हुए तथा कहीं दूसरी जगह इस जिज्ञासा को पूर्ण करने के लिए नहीं जाना पड़ा। आपको वाद्य वादन का ज्ञान अपने दादा स्व० चिंघाडू राम तथा पिता श्री कुन्दन सिंह से प्राप्त हुआ। नगाड़ा वाद्य के अलावा आप

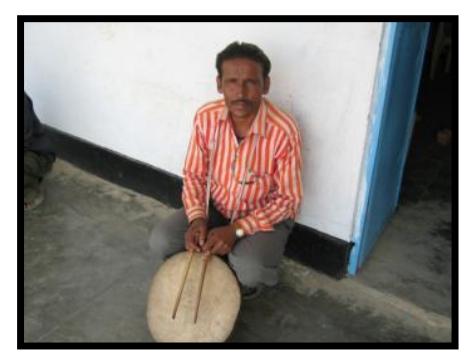
दुमैनू, करनाल, ढोल तथा रणसिंगा भी बजाते हैं। आप विवाह शादियों तथा मन्दिर में नगाड़ा वादन करते हैं। घर में गरीबी का साया होने के कारण आप पाठशाला में पढ़ाई के लिए नहीं जा पाए तथा जो कुछ सीखा वह घर में ही सीखा। आप महाकाली लोक वाद्य दल (अन्धेरी) के सदस्य कलाकार हैं तथा अपनी पूरी तैयारी के साथ सामूहिक आयोजनों मेंलों तथा विवाहोत्सवों में वादन करते हैं। आप अपने दो बेटों विजय एवं दीपक को भी वाद्य वादन की शिक्षा दे रहे हैं।

\section{जोगिन्दर}

ढोल वादक जोगिन्दर का जन्म रेणुका जी विधान सभा क्षेत्र की संगड़ाह तहसील के कशलोग गाँव में 4 जून 1974 को श्री बुद्ध राम जी के घर हुआ। आप ने ढोल वाद्य को बजाना अपने पुर्वजों से ही सीखा। ढोल के अलावा आप नगाड़ा एवं ढोलक भी बजाते हैं तथा सिरमौरी लोक गीतों का तथा रिति रिवाजों का अच्छा ज्ञान रखते हैं।

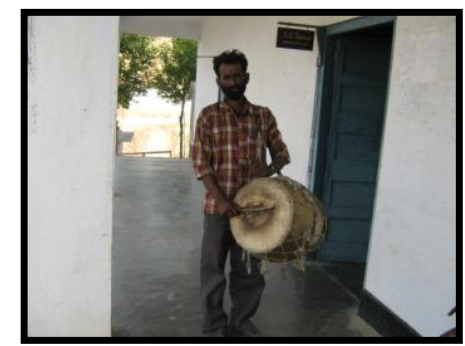


आप लगभग दस वर्ष की आयु से लेकर ढोल बजा रहे हैं। विवाह-शादियों, मेलों अथवा जन्मोत्सव आदि के कार्यक्रमों में आप पारम्परिक महाकाली लोक-वाद्य दल अन्धेरी के साथ वाद्य वादन करते हैं। आप अपने ग्राम देवता के मन्दिर में भी वाद्य वादन करते हैं आपके पिता जी और स्वर्गीय दादा जी ढोल व नगाड़ा के अच्छे वाद्य वादक हुए हैं जिन्होंने विवाह शादियों में तथा बिशु मेलों में लोगों को खूब नचाया है तथा उनका भरपूर मनोरंजन किया है। आप अपने पूर्वजों की विरासत को अपने पारिवारिक जीवन में संजोए हुए हैं तथा ईमानदारी से उसका निर्वाह कर रहे हैं।

\section{अमर सिंह}

दुमैनू वादक अमर सिंह का जन्म सन् 1964 के लगभग संगड़ाह तीहसील के लगनू गाँव के एक बढ़ई परिवार में हुआ। आपके पूर्वज बढ़ई का व्यवसाय करते आ रहे हैं। किसी ने भी गाने बजाने का काम नहीं किया था। आपने इस वाद्य को बजाने की शिक्षा अपने गाँव के एक व्यावसायिक लोक संगीतज्ञ स्वीर्गीय सालिगराम जी से प्राप्त की। दुमैनू वाद्य के साथ-साथ आपने नगाड़ा और ढोलक बजाना भी सीखा। आपने अपने क्षेत्र

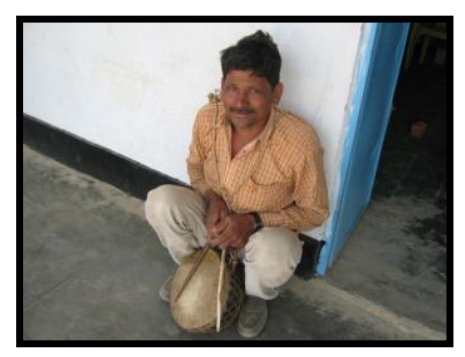
में बजने वाले लोक तालों तथा लोकगीतों की शिक्षा अपने गुरु जी से विधिवत प्राप्त की तथा उनके आप बहुत लाडले रहे। धीरे-धीरे आपने विवाह-शादियों में वाद्य वादन आरम्भ कर दिया तथा इसे अपनी आजीविका कमाने का साधन बना लिया। आप देवता के मन्दिर में भी लोक वाद्य बजाते हैं तथा स्थानीय मेलों में भी वाद्य वादन करते हैं। आपके परिवार के सदस्य बढ़ई का कार्य करते हैं।

\section{बलदेव चौहान}

छड़ी की ढोल के वादक कलाकर बलदेव चौहान का जन्म सिरमौर जिला के पच्छाद विधान सभा क्षेत्र की राजगढ़ तहसील के शरगाँव में 2 जुलाई सन् 1974 को स्व० हसिया राम के घर हुआ। आपके पूर्वज व्यवसाय से कृषक थे और अच्छी खेती-बाड़ी आज भी आपके परिवार के लोग कर रहे हैं आपकी बाल्यावस्था से ही संगीत के प्रति रूची थी। अपने शौक को पूरा करने के लिए आपने श्री नारायण दत्त शर्मा जी से तबला वादन सीखा तथा तबला विशारद की परिक्षा सन् 1992 में पास की,

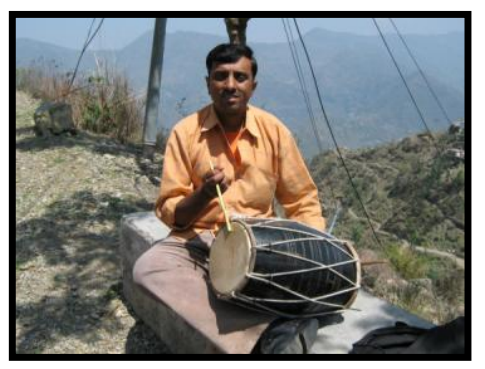
आपका लोक वाद्यों की ओर ज्यादा झुकाव रहा आपने छड़ी के ढोल का चुनाव किया तथा अपने सिरमौर क्षेत्र में बजने वाले लोक तालों का अच्छा मन्थन किया। आपको लोक संगीत की संध्या में विशेष रूप से आमन्त्रित किया जाता है आप प्रतिदिन तीन और चार घण्टे तक वाद्य वादन का अभ्यास करते हैं। आप सिरमौरी लोकगीतों की बहुत सी कैसेट रिकॉडिंग में संगत कर चुके हैं तथा हिमाचल प्रदेश का प्रतिनिधित्व करने वाली सिरमौरी सांस्कृतिक दल के साथ भारत के कई प्रान्तों में कार्यक्रम पेश कर चुके हैं।

\section{गुमान सिंह}

ढोल वादक गुमान सिंह का जन्म संगड़ाह तहसील के सांगणा स्थान गांव में 1 मार्च 1988 को श्री तेलू राम के घर में हुआ। अपनी पांचवी कक्षा तक की पढ़ाई रा०हा० स्कूल सांगणा स्थान से प्राप्त की तत्पश्चात पढ़ाई छोड़ दी। आपने ढोल बजाने की कला अपने पिता जी तथा अन्धेरी के श्री जोगिन्दर धीमान, ग्वानल के वयोवृद्ध लोक संगीतज्ञ श्री जालम सिंह जी से सीखी। आपने सिरमौरी लोक तालों को अच्छे ढंग से सीखा है तथा उन्हें बखूबी

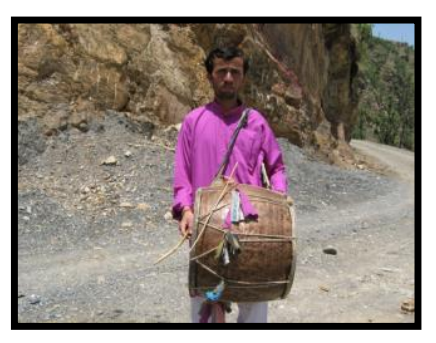
बजाते हैं, वे चाहे नाटी के ताल हों या देव पूजा के ताल। मन्दिर में बजाने के अलावा आप विवाह शादियों में तथा मेलों में वाद्य वादन करते हैं। आप एक हंस मुख एवं खुश मिज़ाज युवा कलाकार हैं। आपकी लोक वाद्यों को बजाने एवं सिखाने में अच्छी सूझ-बूझ है। ढोल वाद्य के वादन से साथ-साथ करनाल, ढोलक तथा नगाड़ा भी बजाते हैं। 


\section{जोगिन्दर सिंह}

जोगिन्दर सिंह दुमैनू वादक का जन्म सिरमौर जिला के रेणुका जी तहसील के कड़ोली गांव में 5 अप्रैल सन् 1967 को स्वर्गीय जीत राम जी के घर में हुआ। गीत तथा नृत्य की शिक्षा आपको परिवार में ही मिली। प्राईमरी तक की परीक्षा पास करके आपने पाठशाला की पढ़ाई छोड़ दी उसके वाद आपने पिता जी के साथ कृषि कार्य में सहयोग देना शुरू कर दिया। छोटी अमर में ही आपकी शादी कर दी गई और परिवार का बोझ भी

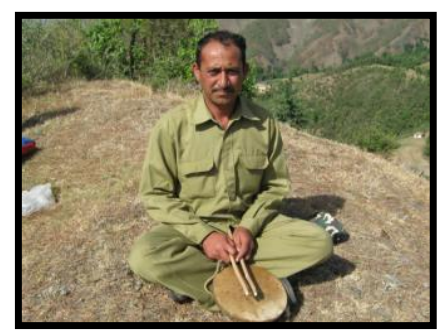
आपके उपर पड़ गया आपने वाद्य वादन के साथ गाने में भी खूब निखार लाया। आप लोक गीत बहुत ही मधुर स्वर में गाते हैं तथा नृत्य में खूब रंग जमाते हैं। दुमैनू के साथ-साथ आप हुलकी भी अच्छा बजाते हैं। आप लोक संगीत के एक अच्छे कलाकार हैं। आपके परिवार में आपकी दो पत्नीयां एवं पांच बच्चे हैं।

\section{केवल राम}

ढोल वादक केवल राम का जन्म शिलाई विधान सभा क्षेत्र के नैणीधार गाँव में श्री बुद्धि राम जी के घर 20 दिसम्बर सन् 1977 को हुआ। परिवार में पढ़ने-लिखने की ओर कोई विशेष रूची न होने के कारण आपको पांचवीं कक्षा तक ही पाठशाला में पढ़ने का अवसर मिला। पिता जी से ढोल बजाना भी सीखा और तेरह चौदह वर्ष की आयु में अच्छा ढोल बजाने लग गए। आप महासू देवता के मन्दिर में ढोल बजाते हैं तथा जब

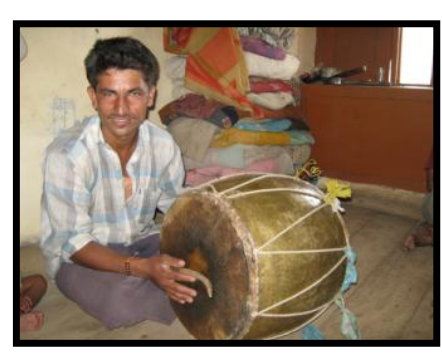
भी देवता यात्रा में जाते हैं उनके साथ आप वाद्य वादन करते हैं। आप विवाह शादियों, मेलों तथा जन्मोत्सव में भी वाद्य वादन करते हैं। ढोल वाद्य के अतिरिक्त आप नगाड़ा, ढोलक तथा करनाल वाद्य बजाना भी भली-भान्ति जानते हैं। आपका परिवार कई पीढ़ियों से सिरमौरी लोक संगीत की लोक-वाद्य रूपी धरोहर को पीढ़ी दर पीढ़ी आगे ले जा रहा है।

\section{सुरेन्द्र धीमान}

ढोल वादक सुरेन्द्र धीमान का जन्म 1 जुलाई 1981 को शिलाई तहसील के नैणीधार गाँव में हुआ। आपके पिता जी एक किसान हैं तथा खेती-बाड़ी के साथ-साथ बढ़ई का काम भी करते हैं। परिवार में संगीत मय वातावरण ने आपको भी लोक वाद्य बजाने के लिए प्रेरित किया और आप भी वाद्य-वादक बन गए। आपने पाठशाला से पांचवीं कक्षा तक पढ़ाई की और खानदानी व्यवसाय बढ़ई के कार्य तथा लोक वाद्य बजाने में मेहनत शुरू

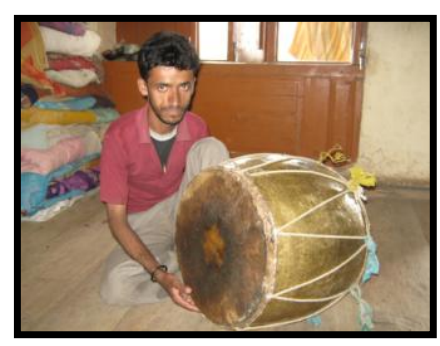
कर दी। ढोल वाद्य आप बहुत ही अच्छा बजाते हैं, इसके अलावा आप नगाड़ा तथा बांसुरी बजाने का भी शौक रखते हैं। आपने लगभग तेरह वर्ष की आयु में अच्छा ढोल बजाना शुरू कर दिया था। सिरमौरी लोक वाद्यों को बजाने का ज्ञान आपको अपने पूर्वजों से प्राप्त हुआ। आप स्थानीय देव मन्दिर के अतिरिक्त विवाह शादियों तथा मेलों में लोक वाद्य बजाने का कार्य करते हैं।

\section{विनोद धीमान}

युवा नगाड़ा वादक विनोद धीमान का जन्म शिलाई तहसील, जिला सिरमौर के गांवनैणी धार में श्री रामसाह के घर 5 सितम्बर सन् 1987 को हुआ। आपने पाठशाला में आठवीं कक्षा तक पढ़ाई की तत्पश्चात पढ़ाई छोड़ दी। आप एक परिश्रमी व्यक्ति हैं तथा अथक प्रयास करने में ही आप सन्तुष्ट रहते हैं। आपको नगाड़ा वादन की शिक्षा अपने परिवारिक माहौल में ही अपने पूर्वजों से मिली। आप बचपन से ही सिरमौरी लोक गीत गाने

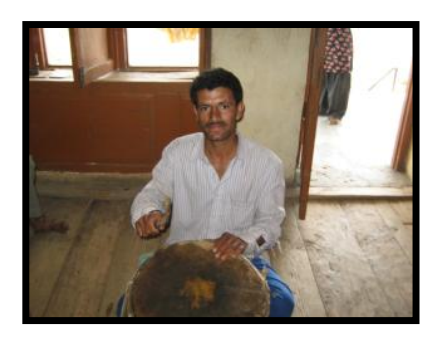
व लोक वाद्य बजाने का शौक रखते हैं। यही कारण रहा कि आपने नगाड़ा जैसे वाद्य को बजाना अपना शौक बना लिया। आप विवाह शादियों, देव पूजा आदि में वाद्य वादन करते हैं। आपको सिरमौरी लोक तालों का तथा लोक संगीत की भिन्न-भिन्न विधाओं का अच्छा ज्ञान है। वाद्य वादन आपकी प्रथम रूची है तथा कृषि व्यवसाय भी। 


\section{लाल सिंह}

दुमैनू वादक लाल सिंह का जन्म सिरमौर जिला की शिलाई तहसील के नैणीधार गांव में 4 नवम्बर 1966 को एक लुहार परिवार में हुआ आप को बचपन से ही लोक वाद्यों को बजाने तथा लोक-गीत गाने का ज्ञान अपने पिता श्री बेसू राम से प्राप्त हुआ। आपके परिवार के लोगों का व्यवसाय कृषि और लोहे का कारोबार करना तथा लोक वाद्यों का वादन करना रहा है। आपके दादा व परदादा भी यही व्यवसाय करते थे। आपको यह सब

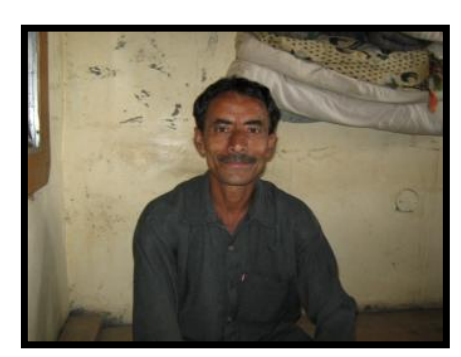
पुर्वजों की विरासत मिली है। आप दुमैनू वाद्य के अच्छे वादक हैं इसके अतिरिक्त आप ढोल, ढोलक तथा अन्य दूसरे लोक वाद्यों को बजाने की अच्छी सूझ-बूझ रखते हैं। आप लगभग अठाईस वर्षों से दुमैनू वाद्य का वादन कर रहे हैं। आपने इस वाद्य वादन को अपना प्रथम व्यवसाय तथा शौक के रूप में रखा। आपने कई जगह राज्यस्तरीय, क्षेत्रीय तथा राष्ट्रीयस्तर के मेलों में अपने वाद्य-दल के साथ वाद्य वादन प्रस्तुत किया है।

\section{राजेन्द्र सिंह}

हुलकी वादक राजेन्द्र सिंह का जन्म रेणुका जी विधान सभा क्षेत्र की संगड़ाह तहसील के कड़ोली गांव में 10 अगस्त, 1978 को श्री मोहन लाल के घर में हुआ। आपके परिवार में कई पीढ़ियों से सिरमौरी लोक संगीत फल-फूल रहा है। आपके पिता जी, दादा जी तथा परदादा जी सभी लोक संगीत से जुड़े हुए लोक संगीतज्ञ हैं। लोक गीत, लोक नृत्य तथा लोक वाद्यों का वादन सभी कुछ आपको अपने परिवार में ही आशिर्वाद के रूप

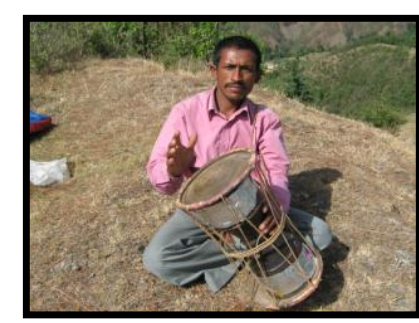
में मिला है। आप हुलकी वाद्य बहुत अच्छा बज़ाते हैं तथा उत्तम श्रेणी के वादक हैं। आपने ने पाठशाला में नौवीं कक्षा तक शिक्षा ग्रहण करके पढ़ाई से छुट्टी कर ली। आपने कई बार अपनी पाठशाला की ओर से सांस्कृतिक कार्यक्रमों समूह गान, एकल गायन तथा वृन्द वादन की स्पर्धाओं में प्रतिनिधित्व करके खूब नाम कमाया है। आप अपनी स्थानीय कलाकार मण्डली के साथ बुढु गायन, करियाला तथा स्थानीय भाषाओं के लोक नाटकों का मंच प्रदर्शन करते हैं तथा वाद्य-वादन के साथ नृत्य करके लोगों का भरपूर मनोरंजन करते हैं।

\section{चेत सिंह}

चेत सिंह का जन्म श्री ज्वाला राम के घर गाँव कड़ोली तहसील संगड़ाह में सन् 1976 में हुआ। आपको (डंऊरू) डमरू बजाने का बचपन से ही शौक था गीत एवं नृत्य आपके परिवार में कई पीढ़ियों से चलता आ रहा है। आपके पुर्वज, हारूल गाने तथा बुढु गायन और रासे के लिए काफी नामी कलाकार रहे हैं। डंऊरू के अतिक्ति आप नगाड़ा

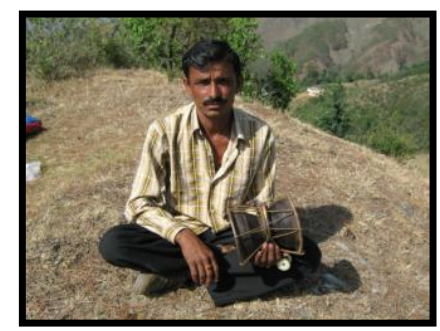
तथा दुमैनू भी बजाते हैं। आपके साथी कलाकार और स्वयं आप वाद्य वादन के साथ लोक गीतों की मधुर बौछार करने के भी माहिर हैं। आपने आठवीं कक्षा तथा पढ़ाई करने के पश्चात पढ़ाई छोड़ दी तथा कृषि एवं गृह कार्य के साथ गीत नृत्यादि आपकी आजीविका का साधन है।

\section{मांगा राम}

सिरमौर जनपद् का ढ़ाकुली वाद्य एक प्राचीन वाद्य है। इसे बजाने वाले वाद्य वादकों की संख्या शून्य के बराबर है। सिरमौर जनपद् में लोक वाद्यों को बजाने वाले अधिकतर लोग निम्न वर्ग के हैं उच्च वर्ग के नहीं हैं। ढाकुली वाद्य को भी जाति विशेष के ही लोग बजाते हैं। जिनकी संख्या बहुत ही कम है। ढ़ाकुली वादक मांगा राम का जन्म श्री धौकलू राम के घर सन् 1949 के लगभग रेणुका जी तहसील के गाँव चसोटी में हुआ। इस वाद्य

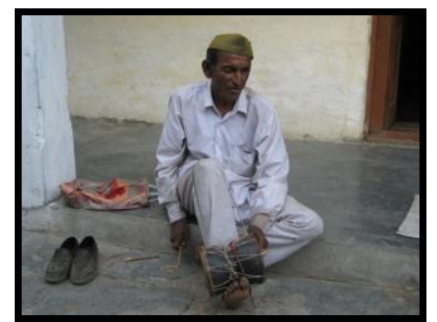
को बजाने का ज्ञान आपको अपने पूर्वजों से प्राप्त हुआ। इस वाद्य को चैत मास में जीणीया नामक गाथा के साथ बजाया जाता है। 
मांगा राम इस वाद्य को 45 वर्षों से बजा रहे हैं तथा चैत मास में हर वर्ष घर-घर जाकर इस वाद्य का वादन करते हैं और जीणीया सुनाते हैं। यह प्राय: नाम मात्र रह चुका है नई पीढ़ी के लोग इसे सिखने में कोई रूची नहीं रखते। आपके अतिरिक्त आपके अनुज शुईया राम आपका सहयोग देते हैं।

\section{सही राम शर्मा}

ख्व० कमिया राम के कनिष्ठ पुत्र सही राम शर्मा का जन्म लगभग सन् 1944 को संगड़ाह तहसील के बाऊनल गाँव में हुआ। आपके परिवार में संगीत दादा एवं परदादा आदि के कई पीढ़ियों से विद्यमान है आपके स्व० पिता जी को गाने बजाने एवं नृत्य का अच्छा ज्ञान था तथा राजा महाराजाओं के समय से अपनी ड्रामा पार्टी थी। अपने गाँव के अतिरिक्त सिरमौर जनपद् के दूसरे गांवों में भी बाऊनल की पार्टी अच्छी धूम मचाती रही है। आप नाटी के साथ ढोलक बजाने में निपुण वादक रहे हैं और अभी भी बजाने की कोशिश करते हैं। आपके परिवार में सभी सदस्य पुरुष

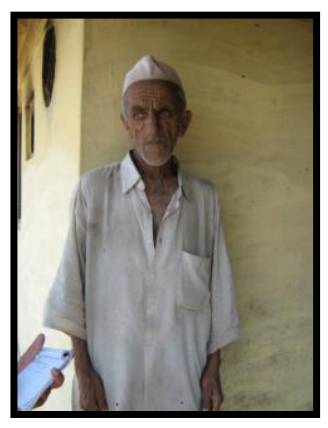
कोई न कोई लोक वाद्य अवश्य बजाते हैं तथा गीत व नृत्य के अच्छे कलाकार है। आपके एक मात्र बेटा नीका राम शर्मा अच्छा ढोलक वादक है। आपका बेटा बाऊनल वाद्य दल के साथ हिमाचल प्रदेश के कई भागों में प्रस्तुति दे चुका है। आपके बेटे के अतिरिक्त आपके पोतों को भी गाने बजाने का अच्छा शौक है।

\section{रविन्दर तोमर}

ढोलक वादकों में एक और अग्रणी नाम श्री रविन्दर तोमर का भी है जो कि एक शिक्षित व्यक्ति हैं। राजनीति शास्त्र में स्नातकोतर हैं तथा प्राथमिक पाठशाला में अध्यापन करते हैं। रविन्द्र तोमर के वादन में मिठास तथा एक अच्छे संगतकार के गुण विद्यमान हैं।

\section{सुषिर वाद्य वादक}

सुषिर वाद्य शहनाई तथा बांसुरी, करनाल, रणसिंगा आदि वाद्यों के वादकों की संख्या सिरमौर जनपद् में बहुत ही कम है। इन वाद्यों के वादक कलाकारों की संख्या कम होने का कारण शायद इन वाद्यों के वादन की जटिलता भी हो सकती है क्योंकि शहनाई तथा बांसुरी वाद्य को सीखने के लिए सतत् साधना, निरन्तर अभ्यास तथा सिखाने वाले अच्छे शिक्षक की आवश्यकता रहती है वह शायद सिरमौर में नहीं के बराबर हैं। यही सुषिर वादकों की कम संख्या का कारण है।

\section{जोगिन्दर सिंह धीमान}

जोगिन्दर सिंह धीमान का जन्म सिरमौर जनपद् के रेणुका जी विधान सभा क्षेत्र में संगड़ाह तहसील के अन्धेरी गाँव में 2 जून 1966 को एक लुहार परिवार में हुआ। आपके पिता श्री शोभा राम जी एक अच्छे लोक गायक एवं विभिन्न प्रकार के लोक वाद्यों के बजाने वाले सुप्रसिद्ध कलाकार थे। सात वर्ष की बाल्यावस्था में ही जोगिन्दर से पिता का प्यार एवं माता का प्यार छिन्न गया। अपने माता-पिता की एक मात्र सन्तान होने के कारण दर-बदर की ठोकरें खाने के लिए मजबूर होना पड़ा। पढ़ाई

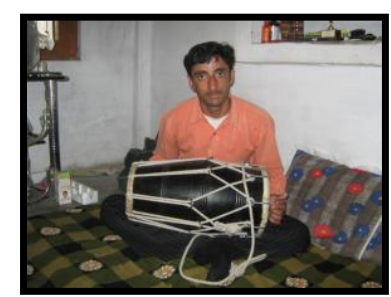
करना भी भाग्य में नहीं था। आपको लोक वाद्यों के बजाने का बचपन से ही शौक था। इस प्रतिभा को निखारने का श्रेय आपके मामा सूरत सिंह तथा धर्म सिंह को जाता है। वाद्यों के वादन सम्बन्धी ज्ञान अर्जित करने का कार्य निरन्तर चलता रहा। विभिन्न प्रकार के वाद्यों जैसे ढोल, नगार-जोड़ी, दुमैनू, ढोलक, हुलकी, रणसिंगा तथा करनाल एवं शहनाई आदि लोक वाद्यों को ज्यों की त्यों नकलन करके बजाने लगे।

आकाशवाणी शिमला से जून 1991 में वाद्यवादन परीक्षा पास की तथा आकाशवाणी शिमला के सिरमौरी लोकसंगीत के कार्यक्रमों की रिकार्डिंग के लिए नेमीतिक वादक के रूप में कार्य किया। आकाशवाणी शिमला के माध्यम से हि०प्र० के विभिन्न क्षेत्रों 
-बिलासपुर, डोडरा क्वार, रिकांगपिओं, रामपुर बुशहर तथा राजस्थान, लक्षद्वीप, उड़ीसा आदि राज्यों में अपनी प्रतिभा एवं कला कौशल को प्रस्तुत करने का अवसर मिला। आपने माँ काली सांस्कृतिक दल अन्धेरी के नाम से लोक वाद्यों के वाद्य वृन्द को तैयार किया। मंच प्रदर्शन के अतिरिक्त आप कैसेट रिकार्डिंग का कार्य करने के लिए स्टूडियों में भी कार्य करने का ज्ञान रखते हैं। आप कई सिरमौरी लोक गीतों की रिकार्डिड कैसेट में धूम मचा चुके हैं। आपकी सिरमौरी ढोलक बजाने में एक अलग पहचान है जो समूचे सिरमौर जनपद् में अपना अलग से स्थान बनाए हुए है। आपके वादन में बोलों की स्पष्टता तथा स्वर माधुर्य समान रूप से विद्यमान रहता है। ढोल हो या नगार जोड़ी, दुमैनू अथवा ढोलक सभी के वादन में आपका एक समान अधिकार है। आप का सादा जीवन और विनम्र स्वभाव आपकी पहचान है।

आपने काफी संख्या में नव युवकों को लोक वाद्यों के वादन की शिक्षा दी है तथा आगे भी सिखा रहे हैं। विभिन्न प्रकार के सिरमौरी लोक वाद्यों पर बजने वाले लोक तालों का आपको अच्छा ज्ञान है और यह भी आपकी पूरे सिरमौर क्षेत्र में पहचान का कारण है।

\section{रमेश सहगल}

शहनाई वादक रमेश सहगल का जन्म 26 दिसम्बर सन् 1962 को स्व० मोही राम जी के घर, गांव संगड़ाह जिला सिरमौर में हुआ। ये संगीत के व्यवसायिक खानदान से सम्बन्ध रखने वाले हैं घर में ढोल नगाड़ा, दुमैनू, शहनाई, ढोलक आदि हर प्रकार के संगीत वाद्यों का होना इनके लिए संगीत सीखना मुश्किल कार्य नहीं था। आपने बाल्यावस्था से ही अपने पूर्वजों से संगीत प्रशिक्षण प्राप्त करना शुरू कर दिया था। गाना सीखने के साथ-साथ शहनाई बजाने में अच्छा अभ्यास करना, गायन व ताल

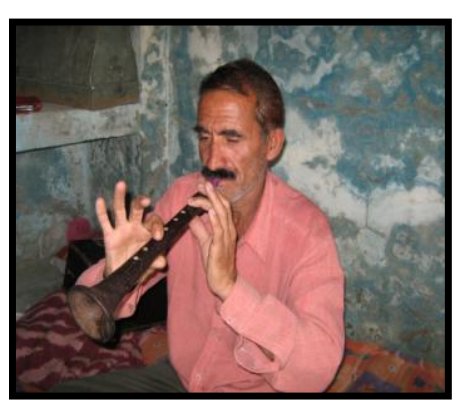
ज्ञान का अच्छा अनुभव होने के कारण शहनाई वादन में आपकी अच्छी पकड़ है। आपके वादन में स्वर माधुर्य की बौछार और स्वभाव में मदमस्ती सदैव झलकती है। आप सिरमौर के प्रसिद्ध देवता 'बिजट महाराज- के मन्दिर में अक्सर हाज़िर होते हैं तथा देवता के साथ निरन्तर शहनाई बजाते हैं। विवाह शादियों तथा मेलों आदि में शहनाई पर लोक धुनों को बजाकर दर्शकों का अच्छा मनोरंजन करते हैं। आपने छ: कक्षा तक पढ़ाई की तत्पश्चात ढोल नगाड़ा और शहनाई बजाकर अपने परिवार का पालन पोषण शुरू किया तथा आज भी इसी के साथ गुजारा कर रहे हैं। इसके अतिरिक्त आप हारमोनियम तबला और ढोलक अच्छा बजा लेते हैं तथा बच्चों को सिखाने का काम भी करते हैं। आप अपने दो बच्चों विनोद सहगल और पवन सहगल को भी पाठशाला की पढ़ाई के साथ-साथ संगीत की शिक्षा भी दे रहे हैं।

\section{चेतराम}

वयोवृद्ध एवं वरिष्ठतम संगीतज्ञ श्री चेतराम जी का जन्म सन् 1919 के लगभग स्व० तुलसी राम जी के घर गांव रावलागढ़ त० रेणुका जी में हुआ। आपका दोनों समय सुबह-शाम मन्दिर जाना तथा पूजा अर्चना करना और वाद्य वादन करना वृद्धावस्था में भी निरन्तर चल रहा है। आपने वाद्यों के वादन का ज्ञान अपने पूर्वजों से विरासत स्वरूप ग्रहण किया तथा अपने खास और खासम खास लोगों को भी इस ज्ञान से अवगत कराया।

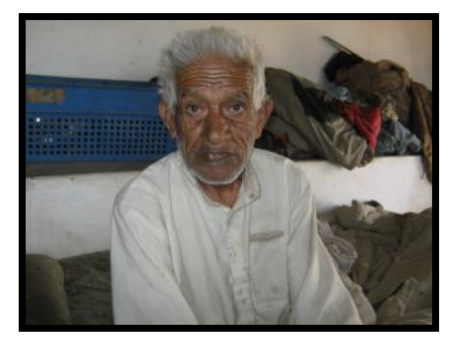
पारम्परिक लोक तालों का आपको अच्छा ज्ञान है। नए बहुत से वाद्य वादकों को शायद इनके नाम तक पता नहीं है। आपके मुखार विन्द से तालों की एक लम्बी श्रृँखला का पता मालूम हुआ जिनमें बिशू की ताल, ब्याधड़ी ताल, जंग ताल, फुलणिया, बधावा, धूप (सन्धुआ) नबद, देव भण्डारना, देव उठाव (शवारी) सड़ा-सेट, उदाल, उकाल, जड़ी भरत, सरगा रहण, घाई, मड़याच इत्यादि लोक तालें जिन्हें पुराने लोक कुछ एक ही जानते थे जो शनैः शनै: संस्कृति से लुप्त होती जा रही हैं। शहनाई के बारे में आपका विचार है कि यह कठिन अभ्यास और बुद्धिबल के प्रयोग से बजने वाला वाद्य है नए लोग इतनी मेहनत नहीं करते इसलिए इसे बजाने वाले लोग बहुत कम होते जा रहे हैं। ढोल एंव नगार जोड़ी वादन जहां निरन्तर विवाह शादियों में और दूसरे आयोजनों में अत्यधिक होता 
था लोग कई घण्टो तक झूम-झूम कर नृत्य करते थे। वर्तमान समय में इसके महत्व में कमीं आना शुरू हो रही है अब विदेशी वाद्य यन्त्र धीरे-धीरे अपनी पकड़ बना रहे हैं और लोक वाद्यों की पकड़ कुछ ढीली पड़ रही है।

\section{सोहन लाल}

युवा शहनाई वादक सोहल लाल का जन्म श्री भगत राम निवासी घनेच तहसील राजगढ़ जिला सिरमौर के घर 10 फरवरी, 1980 को हुआ। आपने विद्यालय से मात्र पांचवी कक्षा तक पढ़ाई पास करके पाठशाला छोड़ दी। तदोपरान्त अपने पिता श्री भगत राम जी के सानिध्य में लोक वाद्यों के सीखना आरम्भ किया आपका शौक बचपन से ही बांसुरी और फ़ंक से बजने वाले वाद्यों को बजाने का था। इस शौक को पूरा करने के लिए आपने शहनाई को चुन लिया

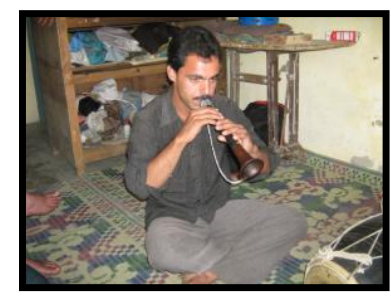
और निरन्तर इस वाद्य जो बजाने के लिए अभ्यास करते हैं। आपके वादन में स्वर माधुर्य स्पष्टतया सुनाई देता है। आप सामूहिक सामाजिक आयोजनों मेलों एवं त्योहारों में शहनाई के मधुर स्वरों की बरसात करते हैं।

\section{डुण्टू राम}

स्वर्गीय बुद्धिया राम के पुत्र एवं बसिया राम शहनाई वादक के शिष्य डुण्टू राम का जन्म गांव जरवा त० शिलाई, जिला सिरमौर सन् 1949 में हुआ। आप शिलाई क्षेत्र के प्रसिद्ध शहनाई वादक हैं। शहनाई वादन की शिक्षा आपको अपने स्व० पिता तथा सुप्रसिद्ध शहनाई वादक श्री बसिया राम जी से मिली। आप देवता बिजट महाराज के मन्दिर के वाद्य-वादक कालाकर हैं, विवाह शादियों तथा मेलों में वाद्य वादन करते हैं। आप पारम्परिक लोक वाद्य दल जरवा के सदस्य वादक कलाकार हैं। आप हिमाचल के अनेक स्थानों में लोक वाद्यों के वादन की प्रस्तुती दे चुके हैं। रेणुका जी मेले में हर वर्ष

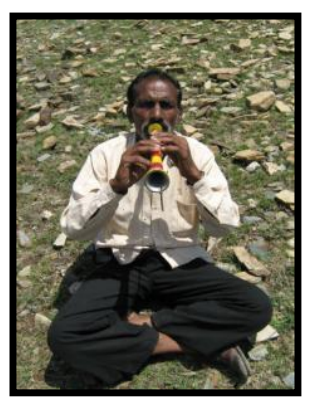
वाद्य वादन की प्रस्तुती देते हैं। शहनाई वाद्य को बजाने का आपका लगभग 45 वर्ष का अनुभव है। अपने परिवार में आप अपने एक पुत्र सुभाष को शहनाई वाद्य की शिक्षा दे रहे हैं। आप शहनाई पर सिरमौरी लोक गीतों की धुनें बखूबी बजाते हैं तथा लोगों का भरपूर मनोर०जन करते हैं।

\section{बलवीर सिंह}

सिरमौरी युवा शहनाई वादक बलवीर सिंह का जन्म रेणका जी तहसील के गाँव ग्वानल में सन् 1991 में हुआ। आपको लोक संगीत रूपी अमृत अपने पुर्वजों की अमानत स्वरूप परिवार में ही मिला। आपने ही अपने परिवार में दसवीं कक्षा तक की पढ़ाई की है, आपके इस शौक को दिशा देने में आपके पिता श्री दुलाराम तथा दादा वयोवृद्ध संगीतज्ञ श्री जालम सिंह का

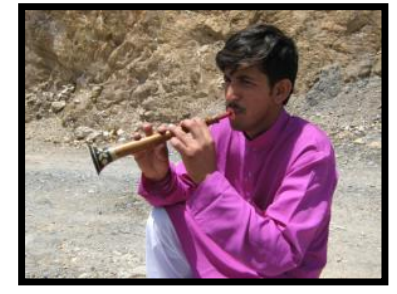
विशेष योगदान है। आपकी प्रतिभा को निखारने का कार्य जोगिन्दर सिंह धीमान अन्धेरी वाले कर रहे हैं। शहनाई वाद्य को अपनी आजिविका का साधन बनाने का आपका विचार पूरी तरह पक्का है। आप एक दृढ़ निश्चय वाले युवक है तथा अधिक से अधिक परिश्रम करने में विश्वास रखते हैं। आपने पाठशाला में आयोजित सांस्कृतिक कार्यक्रमों तथा स्पर्धाओं में कई बार पुरूस्कार प्राप्त किए हैं। शहनाई के साथ-साथ ताल वाद्यों, ढोल, नगाड़ा, दुमैनू तथा रणसिंगा एवं करनाल बजाने का भी आप शौक रखते हैं।

\section{सतपाल}

बांसुरी वादक सतपाल सपुत्र स्व० कली राम का जन्म रेणुका जी विधान सभा क्षेत्र की संगड़ाह तहसील के कड़ोली गांव में एक कृषक परिवार में 9 मार्च, 1976 को हुआ। आपके पिता स्वर्गीय कली राम जी नगाड़ा एवं हुलकी वाद्य बजाते थे। संगीत का शौक आपको बांसुरी वाद्य की तरफ खींच कर ले गया। आपने पाठशाला से प्राथमिक परीक्षा पास की तथा पढ़ाई छोड़कर गृह कार्य एवं कृषि में अपने पिता का सहयोग देने लगे। बांसुरी की ओर

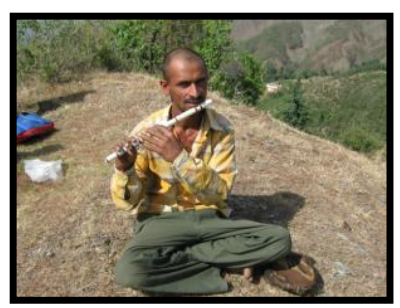
आकृष्ट करने में आपके स्व० दादा श्री धूंरा राम जी का भी काफी योगदान है। आप इस वाद्य पर हिमाचली लोक गीतों एवं सिरमौरी 
लोकगीतों की धुनों को अच्छी तरह बजाते हैं। आप सामूहिक नृत्य, बुढ़, हारूल के साथ स्वर माधुर्य की अच्छी बौछार करते हैं। आपके परिवार में आपके अनुज गोपाल तथा तीन बेटे राहुल, सुनील एवं गोबिन्द लोक संगीत में अच्छी रूची रखते हैं।

\section{जीवन सिंह}

करनाल एवं रणसिंगा वादक जीवन सिंह का जन्म सन् 1965 में गांव जरवा तहसील शिलाई में स्व० दांगी राम के घर में हुआ आप संगीत व्यवसायी जाति ढाकी से सम्बन्ध रखते हैं। संगीत की शिक्षा आपको अपने पिता जी तथा दादा जी से विरासत में मिली, आपका शौक करनाल बजाने में है। इस वाद्य वादन के लिए एक लम्बे समय तक श्वास प्रक्रिया की आवश्यकता रहती है। इसके साथ इसे बजाने के लिए लय और ताल का ज्ञान भी आवश्यक

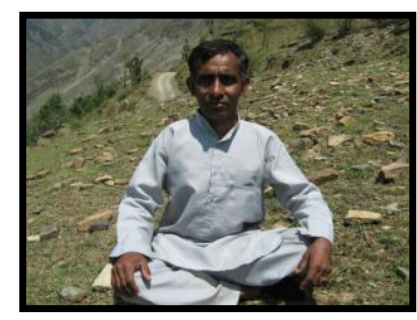
है इन सभी का अभ्यास आपको विधिवत कराया गया है। इस वाद्य के वादन के अलावा आप ढोल, दुमैनू तथा ढोलक वाद्य भी कुशलता से बजाते हैं। आप पारम्परिक वाद्य दल जरवा जनोली के सदस्य वादक हैं आप अपने वाद्य दल के साथ अनेक स्थानों में वादन प्रस्तुत कर चुके हैं। विवाह शादियों, देव पूजा, सामूहिक आयोजनों, मेलों आदि में अनेकों बार वाद्य-वादन कर चुके हैं।

\section{जालम सिंह}

सिरमौरी लोक संगीत के वरिष्ठतम संगीतज्ञ जालम सिंह का जन्म स्व० भजन सिंह निवासी गवानल त० संगड़ाह के घर में सन् 1934 के लगभग हुआ। आपका पूरा जीवन लोक वाद्यों के वादन और प्रशिक्षण के लिए समर्पित है। आप एक सभ्य इन्सान के साथ-साथ एक अच्छे कलाकार भी हैं। आपको वाद्य वादन का ज्ञान अपने स्व० पिता भजन सिंह तथा स्व० दादा गोरकू जी से प्राप्त हुआ। आप अपनी आयु में लगभग पैंसठ वर्षों से इस व्यवसाय से

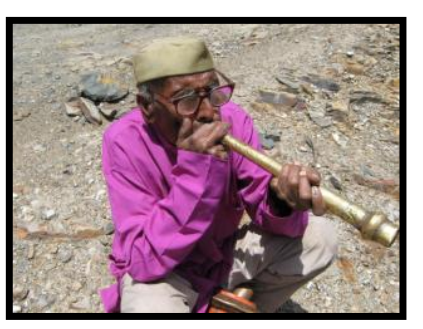
जुड़े हुए हैं। आपके अतिरिक्त आपके परिवार में एक मात्र पुत्र दिला राम लोक वाद्य बजाने का कार्य करते हैं। आप करनाल, नगार जोड़ी, दुमैनू, ढोलक, रणसिंगा तथा ढोल आदि लगभग सभी वाद्यों का ज्ञान रखते हैं तथा नव युवकों को इसका प्रशिक्षण भी देते हैं। आपके शिष्यों में दुला राम, बलवीर सिंह, मोहन लाल, कांशी राम, आत्मा राम, तोता राम आदि के नाम उल्लेखनीय हैं।

\section{मान सिंह}

पच्छाद विधान सभा क्षेत्र की राजगढ़ तहसील के गाँव कोटली निवासी मान सिंह एक प्रसिद्ध करनाल वादक हैं। इनका परिवार कई पीढ़ियों से इस वाद्य का वादन कर रहा है। मान सिंह का जन्म सन् 1954 में स्व0 जालम सिंह प्रसिद्ध करनालची निवासी कोटली के घर में हुआ। वाद्य के वादन का प्रशिक्षण आपको पारिवारिक माहौल में ही प्राप्त हुआ। आप लगभग चालीस वर्षों से करनाल वाद्य का वादन कर रहे हैं। आप देवता शिरगुल के मन्दिर के सदस्य

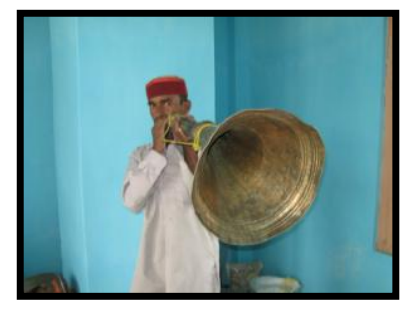
वाद्य वादक कलाकार हैं। लोक वाद्य वादक दलों के साथ आप हिमाचल प्रदेश के राज्य स्तरीय मेलों में लोक वाद्यों के वादन की प्रस्तुतियां दे चके हैं। आपके साथ आप के सहयोगी वादक श्री सुन्दर सिंह (नेरी, राजगढ़) की जोड़ी काफी मशहूर है। आपके दो बेटे हैं, लेकिन परिवार में आगे इस वाद्य को बजाने का किसी को भी शौक नहीं है।

\section{हीरा सिंह}

हीरा सिंह एक युवा रणसिंगा वादक और बहुत ही सरल स्वभाव के व्यक्ति हैं। आपका जन्म रेणुका जी विधान सभा क्षेत्र की संगड़ाह तहसील के कज़वा गांव में 7 जून 1985 को एक कृषक परिवार में हुआ। आपके पिता जी कृषि के साथ-साथ लोहार का काम तथा लोक वाद्य वादन का भी अच्छा शौक रखते हैं। यही कारण रहा कि आपने अपनी बाल्यावस्था से ही यह सब कुछ सीखना आरभ्भ कर दिया। रणसिंगा वाद्य के

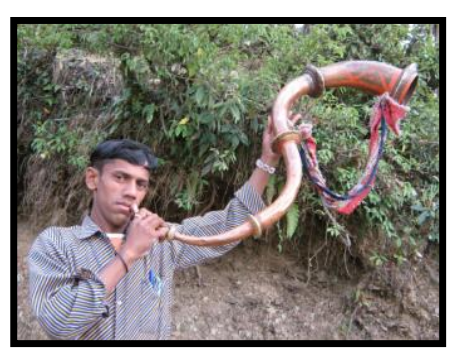
अतिरिक्त आप ढोलक, नगाड़ा आदि वाद्य भी अच्छा बजाते हैं। आप अपने ग्रामीण देवता बिजट महाराज के मन्दिर में भी वादन 
करते हैं तथा विवाह शादियों एवं मेलों में भी लोक वाद्य बजाते हैं। आपने लोक वाद्यों को बजाने की कला अपने पिता श्री सूरत राम जी, चाचा श्री धर्म सिंह जी तथा अन्धेरी के प्रसिद्ध कलाकार जोगिन्दर सिंह धीमान जी से सीखी।

\section{घन वाद्य वादक}

घन वाद्यों के रूप में हमें सिरमौर जनपद् में भायण (घड़ियाल) कांस्य थाली, मंजीरा, चिमटा और छणका आदि वाद्य सम्मिलित हैं। इन वाद्यों को सहायक लय वाद्यों के रूप में दूसरे अन्य ताल वाद्यों के साथ बजाया जाता है। इन्हें कोई भी व्यक्ति बजा लेता है। भायण (घड़ियाल) वाद्य प्रायः देवता के साथ देव कार्य में बजाया जाता है। कांस्य थाली का वादन गुग्गा पीर के गीतों के साथ लय वाद्य के रूप में किया जाता है। मंजीरा वाद्य भजन गीत तथा नृत्य आदि के साथ अवनद्ध वाद्य के वादन के साथ लय वाद्य के रूप में बजाया जाता है। चिमटा वाद्य का प्रयोग भी दूसरे वाद्यों के साथ लय वाद्य के रूप में ही किया जाता है इन वाद्यों के वादन के लिए कोई विशेष अभ्यास अथवा शिक्षा लेने की आवश्यकता नहीं होती। जो व्यक्ति हाथ से लय में ताली बजाता है वह इन वाद्यों को सरलता से बजा लेता है। मंजीरा, तथा चिमटा आदि वाद्य महिलाएं गीत तथा भजन के साथ बखूबी बजाती हैं।

\section{श्री मनीराम शर्मा}

श्री मनीराम शर्मा वरिष्ठतम सिरमौरी लोक वादक कलाकार का जन्म 20 अगस्त सन् 1928 को गांव बाऊनल तहसील संगड़ाह जिला सिरमौर में हुआ। आपके घर में गाने बजाने एवं नृत्य का अच्छा माहौल था। आपने भी अपना शौक पूरा करने के लिए घड़ा बजाना शुरू कर दिया तथा सिरमौरी नाटियों के साथ अच्छी संगत करने लगे, आप की अब वृद्धावस्था है तथा लगभग अंग-अंग शिथिल हैं। आपने गृह कार्य करने के साथ-साथ नृत्य गीत आदि को भी नहीं छोड़ा तथा घर में सबसे बड़े होने के नाते अपने छोटे भाई बहनों का पालन पोषण भी किया तथा अपने

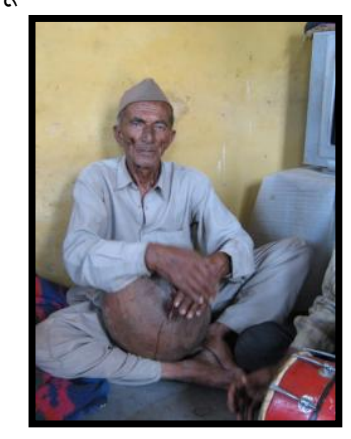

छ: बच्चों, बेटों तथा बेटियों का भी पालन-पोषण किया। संगीत की सेवा का कार्य निरन्तर चला रहा। आपने अपने गाँव की नाटक मण्डली में लगभग 60 वर्षों तक कार्य किया। सिरमौर जनपद् में आयोजित मशराली अथवा बुढ़ी दीवाली में स्थानीय भाषा में जो नाटकों का मंचन होता है उसमें आपने अच्छी भूमिकाएं निभाई हैं तथा अपने घर में अच्छा संगीतमय वातावरण बनाया। आपके द्वारा संचालित बाऊनल कला मंच अभी तक कार्य कर रहा है तथा हिन्दुस्तान ही नहीं इस मंच के कलाकार विदेशों में भी सिरमौरी लोक संगीत की छटा बिखेर चुके हैं। आपके घर में हर संगीतज्ञ अतिथि का अच्छा सम्मान किया जाता है तथा घर में हर प्रकार के लोक संगीत के सिरमौरी लोक वाद्य मौजूद हैं, गाना एवं वाद्य प्रशिक्षण का कार्य निरन्तर चला रहता है। 